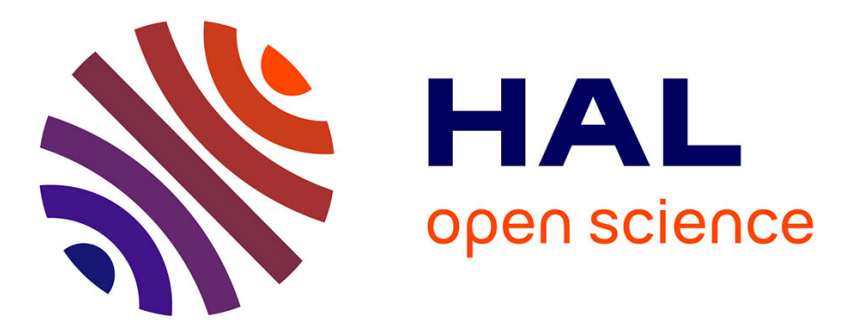

\title{
Native, but not thermally denatured lactoferrin solubilizes iron in the presence of bicarbonate ions.
}

Hiroshi M. Ueno, Ken Kato, Noriko Ueda, Hirokazu Matsui, Hadjime

Nakajima

\section{- To cite this version:}

Hiroshi M. Ueno, Ken Kato, Noriko Ueda, Hirokazu Matsui, Hadjime Nakajima. Native, but not thermally denatured lactoferrin solubilizes iron in the presence of bicarbonate ions.. Dairy Science \& Technology, 2012, 92 (1), pp.25-35. 10.1007/s13594-011-0040-7 . hal-00875673

\section{HAL Id: hal-00875673 https://hal.science/hal-00875673}

Submitted on 22 Oct 2013

HAL is a multi-disciplinary open access archive for the deposit and dissemination of scientific research documents, whether they are published or not. The documents may come from teaching and research institutions in France or abroad, or from public or private research centers.
L'archive ouverte pluridisciplinaire HAL, est destinée au dépôt et à la diffusion de documents scientifiques de niveau recherche, publiés ou non, émanant des établissements d'enseignement et de recherche français ou étrangers, des laboratoires publics ou privés. 


\title{
Native, but not thermally denatured lactoferrin solubilizes iron in the presence of bicarbonate ions
}

\author{
Hiroshi M. Ueno • Ken Kato • Noriko Ueda • \\ Hirokazu Matsui • Hadjime Nakajima
}

Received: 25 January 2011 /Revised: 14 June 2011 / Accepted: 14 June 2011 /

Published online: 5 August 2011

(C) INRA and Springer Science+Business Media B.V. 2011

\begin{abstract}
Lactoferrin (Lf) can solubilize more than a 70-fold molar equivalent of iron in the presence of bicarbonate anions. Iron solubilized by $\mathrm{Lf}(\mathrm{FeLf})$ is a useful food product for iron fortification, preventing anaemia with no risk of toxicity. However, the mechanism underlying this iron solubilization is not yet well understood. The objective of this study was to investigate the effects of thermal treatments on the iron-solubilizing capacity of $\mathrm{Lf}$ in the presence of sodium bicarbonate. Lf was subjected to thermal treatment at $50-80{ }^{\circ} \mathrm{C}$ for $10 \mathrm{~min}$, and the Lf heated to over $70{ }^{\circ} \mathrm{C}$ was precipitated by the addition of Fe(III). No precipitation was observed in FeLf-like mixtures of heated Lf when various other cations were substituted for $\mathrm{Fe}(\mathrm{III})$ : $\mathrm{Cu}(\mathrm{II}), \mathrm{Zn}(\mathrm{II}), \mathrm{Mg}$ or $\mathrm{Na}$. The precipitation was related to the degree of thermal denaturation of Lf, accompanied by the formation of high-molecular-weight aggregates as disulphide bonds were established. Transferrin, $\alpha$-lactalbumin and $\beta$-lactoglobulin did not solubilize Fe(III), suggesting that the Fe(III)-solubilizing capacity is characteristic of Lf. In conclusion, native $\mathrm{Lf}$ is responsible for iron solubilization in the presence of bicarbonate anions. Owing to the application of native Lf to the manufacture of FeLf, FeLf can improve specific food products by supplementing their iron content.
\end{abstract}

H. M. Ueno $\cdot$ K. Kato $(\bowtie) \cdot$ N. Ueda $\cdot$ H. Nakajima

Milk Science Research Institute, Megmilk Snowbrand Co., Ltd., 1-1-2 Minamidai, Kawagoe, Saitama 350-1165, Japan

e-mail: k-kato@meg-snow.com

H. M. Ueno

e-mail: hiroshi-ueno@meg-snow.com

N. Ueda

e-mail: n-ueda@meg-snow.com

H. Nakajima

e-mail: hadjime-nkjm@meg-snow.com

H. Matsui

Graduate School of Agriculture, Hokkaido University, Kita 9 Nishi 9, Kita-ku, Sapporo, Hokkaido 060-8589, Japan

e-mail: mhiro@chem.agr.hokudai.ac.jp 


\section{碳酸氢盐溶液中乳铁蛋白对铁的溶解作用}

摘要 在碳酸氢盐溶液中乳铁蛋白 $(\mathrm{Lf})$ 可以溶解超过其自身摩尔浓度 70 倍的铁。生成的LF与 铁的复合物 (FeLf)通常在食品中作为铁的强化剂用来预防贫血。但是人们对Lf溶解铁的机 制认识还是非常有限。本文研究了在碳酸氢钠存在下, 热处理对Lf溶解铁的影响。Lf分别在 50 80 ${ }^{\circ} \mathrm{C}$ 下处理 $10 \mathrm{~min}$, 然后在 $70{ }^{\circ} \mathrm{C}$ 下加入 $\mathrm{Fe}(\mathrm{III})$ 沉淀热处理过的 $\mathrm{Lf}$ 。当用其它阳离子 $\mathrm{Cu}$ (II)、 $\mathrm{Zn}(\mathrm{II}) 、 \mathrm{Mg} 、 \mathrm{Na}$ 代替Fe(III)时, 没有观察到生成类似的FeLf混合物。生成沉淀的量 与Lf热变性的程度有关, 原因是二硫键的作用Lf形成了高分子凝聚物。转铁蛋白、 $\alpha$-乳白蛋 白和 $\beta$-乳球蛋白不具有溶解铁的能力; 能够溶解 Fe(III) 是Lf蛋白特有的性质。因此, 在碳酸氢 盐溶液中, 天然的Lf能够溶解铁, 采用天然 Lf生产的FeLf复合物可以作为补铁添加剂用于特定 的食品中。

Keywords Iron $\cdot$ Lactoferrin $\cdot$ Solubility $\cdot$ Heat $\cdot$ Denaturation

关键词 铁·乳铁蛋白・溶解性·热处理 $\cdot$ 变性

\section{Introduction}

Iron is the most abundant trace mineral in humans and animals. The main function of iron is in oxygen transport within the blood and muscle. Iron deficiency is one of the major nutritional problems in the world, especially in infants, children and women of childbearing age (WHO 2008). Iron-fortified foods, such as infant formula, yoghurt and skim milk, have been developed to address the inadequate intake of dietary iron that causes anaemia in populations (Hurrell 1997).

Lactoferrin (Lf) is an iron-binding glycoprotein of the transferrin (Tf) family that occurs in milk and secretory fluids, such as human colostrum and cow's colostral whey (Steijns and van Hooijdonk 2000). The proteins of the Tf family are all glycoproteins, with molecular weights of about $80 \mathrm{~kg} \cdot \mathrm{mol}^{-1}$, and typically exhibit 50-70\% pairwise amino acid sequence identities. The three-dimensional structure of Lf has been clearly demonstrated in crystallographic studies. Lf is folded into $\mathrm{N}$ - and C-lobes, and each lobe has a binding site for a ferric ion, which it binds in a unique synergistic cooperation with a bicarbonate anion (Baker and Baker 2009; Baker et al. 2002).

Bovine Lf can solubilize more than 70 molar equivalents of iron in the presence of bicarbonate anions, which is much higher than the specific iron-binding capacity of Lf (Kawakami et al. 1993). Iron solubilized by Lf (FeLf) has no unacceptable taste, contains more bioavailable iron than ferrous sulphate and does not damage the gastric mucosa of rats, which is severely damaged by both ferrous sulphate and ferrous citrate (Uchida et al. 2006). Therefore, FeLf is a useful food supplement for iron fortification, preventing anaemia with no risk of the toxicity often encountered with general iron supplementation (Motouri et al. 2007). FeLf is also useful as a natural iron stabilizer for food products containing polyunsaturated fatty acids because it confers oxidative stability in the iron-catalyzed oxidation of fish oil (Shiota et al. 2006). Recently, the suppressive effects of FeLf on mental stress and menstrual pain have been reported (Yoshise et al. 2010a, b). According to the structural model of $\mathrm{FeLf}$, the $\mathrm{Fe}^{3+}-\mathrm{HCO}_{3}{ }^{-}$electrostatic interactions between $\mathrm{Lf}$ molecules stabilize the protein molecule, which may facilitate the absorption of iron molecules in vivo ( $\mathrm{Hu}$ et al. 2008). However, the mechanism underlying this iron 
solubilization is not well understood, although this is required if we are to develop applications for FeLf in the food industry, such as in the formulation of food products or manufacturing processes that include thermal treatments. It has been proposed that $\mathrm{Lf}$ is involved in various biological functions, including antimicrobial activities, iron absorption and immunoregulation (Lönnerdal 2009; Wakabayashi et al. 2006). The thermal denaturation of Lf affects several of its biological functions, including its iron-binding, antibacterial and cell growth activities (Kussendrager 1994; Oria et al. 1993; Paulsson et al. 1993).

Therefore, the aims of this study were to investigate the effects of the thermal denaturation of bovine $\mathrm{Lf}$ on iron solubilization in the presence of bicarbonate anions and to confirm that this iron-solubilizing capacity is characteristic of Lf and that iron cannot be substituted with other metals by comparing FeLf with other metal-protein complexes.

\section{Materials and methods}

\subsection{Materials}

Native Lf was prepared from bovine skim milk in a one-step procedure using immobilized monoclonal antibodies directed against bovine Lf (Kawakami et al. 1987). Its purity was estimated to be $>95 \%$ by SDS-PAGE, with the method of Laemmli (1970). Sodium bicarbonate $\left(\mathrm{NaHCO}_{3}\right)$ was of food additive grade and obtained from Wako Pure Chemical Industries (Osaka, Japan). Ferric chloride hexahydrate $\left(\mathrm{FeCl}_{3} \cdot 6 \mathrm{H}_{2} \mathrm{O}\right)$ was of food additive grade and obtained from Junsei Chemical (Tokyo, Japan). Bovine transferrin (Tf), $\alpha$-lactalbumin $(\alpha \mathrm{La})$ and $\beta$ lactoglobulin $(\beta \mathrm{Lg})$ were obtained from Sigma-Aldrich (St Louis, MO, USA). Acetonitrile and trifluoroacetic acid were of high-performance liquid chromatography (HPLC) grade (Wako). All chemical reagents were of analytical grade, unless otherwise specified.

\subsection{Heat treatment of Lf}

A solution of native $\mathrm{Lf}\left(8 \mathrm{mg} \cdot \mathrm{mL}^{-1}\right)$ was prepared in $50 \mathrm{mmol} . \mathrm{L}^{-1}$ sodium bicarbonate $\left(\mathrm{NaHCO}_{3}, \mathrm{pH} 8.5\right)$. Aliquots $(10 \mathrm{~mL})$ were transferred into glass test tubes (16-mm i.d. and 125-mm length; Asahi Glass, Tokyo, Japan), sealed with glass caps and then heated for $10 \mathrm{~min}$ in a water bath at temperatures ranging from 50 to $80{ }^{\circ} \mathrm{C}$. After heating, the heat-treated Lf (HT-Lf) solutions were cooled immediately on ice. All experiments were performed in triplicate to confirm their reproducibility.

2.3 Preparation of FeLf and FeLf-like mixtures of proteins, metals and $\mathrm{NaHCO}_{3}$ (protein/Fe, HT-Lf/Fe and HT-Lf/metal)

FeLf was prepared by mixing $3 \mathrm{~mL}$ of $8 \mathrm{mg} \cdot \mathrm{mL}^{-1}$ Lf in $50 \mathrm{mmol} . \mathrm{L}^{-1} \mathrm{NaHCO}_{3}$ solution and $3 \mathrm{~mL}$ of a $10 \mathrm{mmol} \cdot \mathrm{L}^{-1} \mathrm{FeCl}_{3} \cdot 6 \mathrm{H}_{2} \mathrm{O}$ solution at room temperature. The molecular ratio was $100 \mathrm{~mol}^{\mathrm{mol}} \mathrm{l}^{-1}$ iron per Lf. To determine the effects of the thermal treatment of $\mathrm{Lf}$ on the solubility of iron in the presence of bicarbonate 
anions, the complex was prepared from HT-Lf instead of native Lf (HT-Lf/Fe). To investigate the effects of various cations on the solubility of HT-Lf, HT-Lf/metal was prepared by blending HT-Lf $\left(80{ }^{\circ} \mathrm{C}, 10 \mathrm{~min}\right)$ with various metals chlorides rather than $\mathrm{FeCl}_{3}$ : copper chloride dihydrate $\left(\mathrm{CuCl}_{2} \cdot 2 \mathrm{H}_{2} \mathrm{O}, \mathrm{HT}-\mathrm{Lf} / \mathrm{Cu}\right)$; zinc chloride $\left(\mathrm{ZnCl}_{2}\right.$. HT-Lf/Zn); magnesium chloride dihydrate $\left(\mathrm{MgCl}_{2} \cdot 2 \mathrm{H}_{2} \mathrm{O}, \mathrm{HT}-\mathrm{Lf} / \mathrm{Mg}\right)$; or sodium chloride $(\mathrm{NaCl}$, HT-Lf/Na). Of the HT-Lf solution, $3 \mathrm{~mL}$ was mixed with a solution of $10 \mathrm{mmol} . \mathrm{L}^{-1}$ chloride. The molecular ratio of each metal per $\mathrm{Lf}$ was also $100 \mathrm{~mol}_{\mathrm{mol}}^{-1}$. To examine the capacity of Tf, $\alpha \mathrm{La}$, and $\beta \mathrm{Lg}$ to solubilize Fe(III), these proteins were used instead of Lf to prepare protein/Fe according to the mixing conditions of FeLf described above (Tf/Fe, $\alpha \mathrm{La} / \mathrm{Fe}$ and $\beta \mathrm{Lg} / \mathrm{Fe}$, respectively). In brief, $3 \mathrm{~mL}$ of $8 \mathrm{mg} \cdot \mathrm{mL}^{-1}$ of each protein in $50 \mathrm{mmol} \cdot \mathrm{L}^{-1} \mathrm{NaHCO}_{3}$ and $3 \mathrm{~mL}$ of the $10 \mathrm{mmol} . \mathrm{L}^{-1} \mathrm{FeCl}_{3} \cdot 6 \mathrm{H}_{2} \mathrm{O}$ were mixed at room temperature. The turbidity of the mixtures was measured as the absorbance at $600 \mathrm{~nm}$.

\subsection{Analysis}

\subsubsection{Soluble iron and soluble protein concentrations}

The supernatants of the samples were obtained by centrifugation at $3,000 \times g$ for $10 \mathrm{~min}$. The soluble iron concentration in the supernatant was determined with an ICPS-8000 inductively coupled plasma spectrometer (Shimadzu, Kyoto, Japan). The soluble protein concentrations of $\mathrm{Lf}, \mathrm{Tf}, \alpha \mathrm{La}$ and $\beta \mathrm{Lg}$ in the supernatants were determined with the Bradford protein assay (Bio-Rad Laboratories, Hercules, CA, USA), with a known amount of each protein used as its own standard.

\subsubsection{Native Lf concentration determined by RP-HPLC}

The native Lf concentration in HT-Lf was determined with reversed-phase HPLC (RPHPLC) based on the different peaks produced by native and thermally denatured Lf on the chromatograms. The analysis was performed with an HPLC system consisting of a Waters 2695 Alliance Separation Module (Waters, Milford, MA, USA) interfaced with a Waters 2487 dual-length UV-Vis detector and a Waters Empower 2 data acquisition and manipulation system. RP-HPLC was performed on an Asahipak C4P-50 reversed-phase column $\left(4.6 \times 150 \mathrm{~mm}\right.$; Showa Denko, Tokyo, Japan) at $30^{\circ} \mathrm{C}$. The chromatogram was recorded at $280 \mathrm{~nm}$. Mobile phase A was a mixture of $0.5 \mathrm{~mol} . \mathrm{L}^{-1} \mathrm{NaCl}$ and acetonitrile $(70: 30, v / v)$, containing $0.03 \%(v / v)$ trifluoroacetic acid. Mobile phase B was a mixture of 0.5 mol.L $\mathrm{L}^{-1} \mathrm{NaCl}$ and acetonitrile $(50: 50, v / v)$, containing $0.03 \%(v / v)$ trifluoroacetic acid. For analytical and column-cleaning purposes, the gradient conditions were programmed on the system controller. During the first $10 \mathrm{~min}$, the linear gradient ranged from 9:1 $(\mathrm{A} / \mathrm{B}, v / v)$ to $1: 9(\mathrm{~A} / \mathrm{B}, v / v)$ at a flow rate of $1 \mathrm{~mL}$. $\min ^{-1}$. The column was then washed with mobile phase $B$ for 3 min and equilibrated to the initial conditions. The cycle run time was $15 \mathrm{~min}$.

\subsubsection{Immunoassay of HT-Lf}

HT-Lf was immunoassayed using the latex agglutination technique (Yamauchi et al. 2004), with the Lactoferrin Latex Test Kit (Cosmobio, Tokyo, Japan), according to 
the manufacturer's instructions. The change in the absorbance of the reaction mixture at $650 \mathrm{~nm}$ was measured. The increase in absorbance relative to that of the control (\%) was proportional to the concentration of bovine $\mathrm{Lf}$ in the sample.

\subsubsection{High-performance size exclusion chromatography}

Molecular mass profiles were obtained using high-performance size exclusion chromatography (HPSEC). Aliquots $(20 \mu \mathrm{L})$ of HT-Lf and HT-Lf/Fe $\left(1 \mathrm{mg} \cdot \mathrm{mL}^{-1} \mathrm{Lf}\right)$ were loaded onto the column and eluted with the mobile phase $[27.5 \%(v / v)$ acetonitrile containing $0.05 \%(v / v)$ trifluoroacetic acid] at a flow rate of $0.3 \mathrm{~mL}$. $\min ^{-1}$. Two TSKgel G3000PW $\mathrm{XL}_{\mathrm{XL}}$ columns $(7.5 \times 300 \mathrm{~mm}$; Tosoh, Tokyo, Japan) connected in series with a TSKgel guard column $(6.0 \times 40 \mathrm{~mm}$; Tosoh) were used for the HPSEC analysis. Lf was detected by its absorbance at $280 \mathrm{~nm}$. The HPLC apparatus was as described in Section 2.4.2.

\subsubsection{SDS-PAGE of HT-Lf under reducing and non-reducing conditions}

HT-Lf $(10 \mu \mathrm{g})$ was mixed with sample buffer $\left[0.125\right.$ mol.L ${ }^{-1}$ Tris- $\mathrm{HCl}(\mathrm{pH} 6.8)$, containing 2\%(w/w) SDS, 30\% (v/v) glycerol and $0.002 \%(w / v)$ bromophenol blue] with (reducing conditions) or without (non-reducing conditions) 4\% ( $v / v) 2$ mercaptoethanol. After the samples were boiled for $2 \mathrm{~min}$, they were resolved electrophoretically on a $14 \%$ polyacrylamide gel in a vertical slab gel apparatus (Safety-Cell Mini STC-808; Tefco, Tokyo, Japan) at $200 \mathrm{~V}$ per gel. A cocktail protein standard, consisting of 7-216 kg. mol ${ }^{-1}$ proteins, was also run (Kaleidoscope Prestained Standards, Bio-Rad Laboratories). The gels were stained using Bio-Safe Coomassie Blue G-250 stain (Bio-Rad Laboratories).

\section{Results}

\subsection{Effect of heat treatment of Lf (HT-Lf) on iron solubilization with $\mathrm{HCO}_{3}{ }^{-}$}

Lf was heated at $50-80{ }^{\circ} \mathrm{C}$ for $10 \mathrm{~min}$ in the presence of $\mathrm{HCO}_{3}{ }^{-}$, and then mixtures of HT-Lf and Fe(III) (HT-Lf/Fe) were prepared. Figure 1 shows the appearance of HT-Lf/ $\mathrm{Fe}$, and Table 1 shows the turbidity, the concentrations of soluble Lf and the iron in HT-Lf/Fe. Precipitation was induced by the addition of $\mathrm{FeCl}_{3}$ to HT-Lf treated at $70{ }^{\circ} \mathrm{C}$

Fig. 1 Appearance of the mixture of heat-treated lactoferrin (Lf) and iron(III) chloride in the presence of $\mathrm{NaHCO}_{3}$. Of Lf, $8 \mathrm{mg} \cdot \mathrm{mL}^{-1}$ was heated in $50 \mathrm{mmol} . \mathrm{L}^{-1}$ $\mathrm{NaHCO}_{3}$ at the temperature shown above each test tube for $10 \mathrm{~min}$, and then the mixture was prepared by the addition of the same amount of $10 \mathrm{mmol} . \mathrm{L}^{-1}$ iron(III) chloride

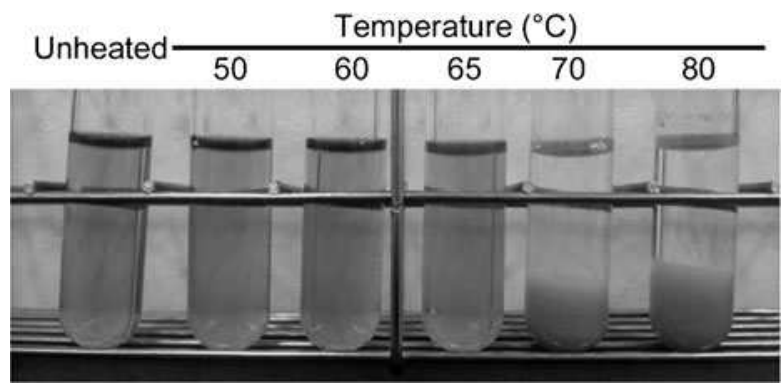


Table 1 Turbidity, soluble lactoferrin (Lf) and soluble iron of the mixture of heat-treated Lf and iron(III) chloride in 25 mmol. $\mathrm{L}^{-1} \mathrm{NaHCO}_{3}$

\begin{tabular}{lccc}
\hline Temperature $\left({ }^{\circ} \mathrm{C}\right)$ & Turbidity $\left(A_{600}\right)$ & Soluble Lf $\left(\mathrm{mg} . \mathrm{mL}^{-1}\right)$ & Soluble iron $\left(\mathrm{mmol}^{-\mathrm{L}^{-1}}\right)$ \\
\hline Unheated & $0.068 \pm 0.012$ & $3.96 \pm 0.07$ & $5.0 \pm 0.1$ \\
50 & $0.075 \pm 0.043$ & $4.53 \pm 0.04$ & $4.9 \pm 0.1$ \\
60 & $0.088 \pm 0.065$ & $4.44 \pm 0.13$ & $5.0 \pm 0.4$ \\
65 & $2.088 \pm 0.113$ & $3.98 \pm 0.06$ & $4.9 \pm 0.1$ \\
70 & $2.221 \pm 0.048$ & N.D. & N.D. \\
80 & $2.210 \pm 0.090$ & N.D. & N.D. \\
\hline
\end{tabular}

All values were shown in mean $\pm \mathrm{SD}(n=3)$

N.D. not detected

or $80{ }^{\circ} \mathrm{C}$ (Fig. 1), and no soluble iron was detected in their supernatants (Table 1). In contrast, $5.0 \mathrm{mmol} . \mathrm{L}^{-1}$ iron still remained in the supernatants of FeLf (unheated) and HT-Lf/Fe treated at $65^{\circ} \mathrm{C}$ or lower temperatures. The turbidity of HT-Lf/Fe increased greatly when HT-Lf was treated at temperatures above $65^{\circ} \mathrm{C}$, whereas the turbidity of HT-Lf/Fe treated at 50 or $60{ }^{\circ} \mathrm{C}$ was low and the solutions looked clear (Fig. 1 and Table 1). The concentration of soluble Lf in HT-Lf/Fe was also markedly reduced by the treatment of HT-Lf at temperatures above $65^{\circ} \mathrm{C}$ (Table 1).

Mixtures were then prepared from various metal chlorides and HT-Lf heated at $80{ }^{\circ} \mathrm{C}$ for $10 \mathrm{~min}$ to examine the effects of other cations on the concentration of soluble Lf. In contrast to HT-Lf/Fe, the soluble Lf concentration changed negligibly in HT-Lf/Cu, HT-Lf/Zn, HT-Lf/Mg and HT-Lf/Na (Table 2).

\subsection{Structural changes in HT-Lf}

The changes induced by the thermal treatment of Lf are summarized in Table 3. At temperatures of $65-80{ }^{\circ} \mathrm{C}$, the turbidity of HT-Lf increased markedly with temperature. In contrast, the native Lf concentration in HT-Lf decreased greatly

Table 2 Soluble lactoferrin (Lf) and turbidity of the mixture of unheated (Lf/Metal) or heat-treated (HTLf/metal) Lf, 5 mmol.L ${ }^{-1}$ metal chloride and 25 mmol.L ${ }^{-1} \mathrm{NaHCO}_{3}$

\begin{tabular}{|c|c|c|c|c|}
\hline \multirow[t]{2}{*}{ Metal } & \multicolumn{2}{|c|}{ Soluble Lf (mg.mL $\left.L^{-1}\right)$} & \multicolumn{2}{|c|}{ Turbidity $\left(A_{600}\right)$} \\
\hline & Lf/metal & HT-Lf/metal & Lf/metal & HT-Lf/metal \\
\hline $\mathrm{Fe}(\mathrm{III})$ & $3.96 \pm 0.07$ & N.D. & $0.068 \pm 0.012$ & $2.210 \pm 0.090$ \\
\hline $\mathrm{Cu}(\mathrm{II})$ & $4.13 \pm 0.05$ & $4.74 \pm 0.21$ & $0.116 \pm 0.016$ & $0.608 \pm 0.049$ \\
\hline $\mathrm{Zn}(\mathrm{II})$ & $4.16 \pm 0.06$ & $4.68 \pm 0.13$ & $0.065 \pm 0.031$ & $0.359 \pm 0.108$ \\
\hline $\mathrm{Mg}$ & $4.14 \pm 0.03$ & $4.77 \pm 0.09$ & $0.007 \pm 0.005$ & $0.047 \pm 0.002$ \\
\hline $\mathrm{Na}$ & $4.20 \pm 0.03$ & $4.83 \pm 0.17$ & $0.006 \pm 0.007$ & $0.050 \pm 0.006$ \\
\hline No metal & $4.04 \pm 0.14$ & $4.87 \pm 0.12$ & $0.005 \pm 0.003$ & $0.081 \pm 0.004$ \\
\hline
\end{tabular}

HT-Lf was heated at $80^{\circ} \mathrm{C}$. All values were shown in mean $\pm \mathrm{SD}(n=3)$

N.D. not detected 
Table 3 Turbidity, native lactoferrin (Lf) concentration and immunological reactivity in heat-treated Lf

Temperature $\left({ }^{\circ} \mathrm{C}\right) \quad$ Turbidity $\left(A_{600}\right) \quad$ Native Lf $\left(\mathrm{mg} \cdot \mathrm{mL}^{-1}\right) \quad$ Immunological reactivity $(\%$ of unheated $)$

\begin{tabular}{lllc}
\hline Unheated & $0.006 \pm 0.002$ & $8.00 \pm 0.06$ & $100 \pm 0$ \\
50 & $0.005 \pm 0.002$ & $8.07 \pm 0.02$ & $104 \pm 5$ \\
60 & $0.007 \pm 0.001$ & $7.55 \pm 0.02$ & $109 \pm 9$ \\
65 & $0.038 \pm 0.005$ & $1.77 \pm 0.63$ & $31 \pm 16$ \\
70 & $0.062 \pm 0.014$ & N.D. & N.D. \\
80 & $0.093 \pm 0.022$ & N.D. & N.D. \\
\hline
\end{tabular}

$8 \mathrm{mg} \cdot \mathrm{mL}^{-1}$ lactoferrin in $50 \mathrm{mmol} . \mathrm{L}^{-1} \mathrm{NaHCO}_{3}, \mathrm{pH}$ 8.5. All values were shown in mean $\pm \mathrm{SD}(n=3)$ N.D. not detected

above $65{ }^{\circ} \mathrm{C}$ and correlated with the change in the immunological reactivity of the solution to anti-Lf antibody. We noted that no precipitation occurred in any HT-Lf (data not shown). The molecular mass profiles of HT-Lf, HT-Lf/Fe and FeLf (unheated) were obtained with HPSEC analysis (Fig. 2). In the chromatograms of HT-Lf, the peak heights of native Lf decreased as the temperature increased, whereas a peak with a shorter retention time, corresponding to the Lf aggregate, appeared above $65{ }^{\circ} \mathrm{C}$ (Fig. 2a). The molecular mass profile of HT-Lf/Fe was complex and differed from that of HT-Lf (Fig. 2b). No peak was observed for HT-Lf/Fe treated at 70 or $80{ }^{\circ} \mathrm{C}$. SDS-PAGE was performed to characterize the thermal denaturation of HT-Lf (Fig. 3). The aggregated proteins appeared at the top of stacking gel under non-reducing conditions, whereas the SDS-PAGE pattern under reducing condition revealed that aggregated $\mathrm{Lf}$ dissociated into the monomeric form, with an apparent molecular weight of $80 \mathrm{~kg} \cdot \mathrm{mol}^{-1}$.
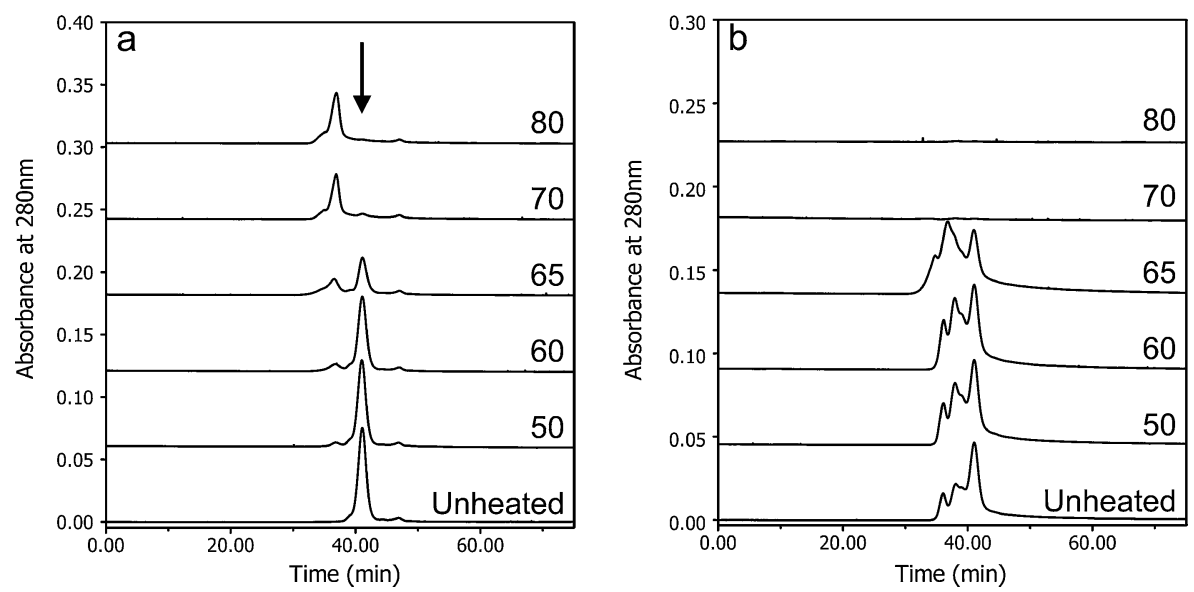

Fig. 2 Chromatograms of heat-treated lactoferrin (Lf) (a) and the mixture of heat-treated Lf and iron(III) chloride (b) obtained by high-performance size exclusion chromatography. Samples (20 $\mu \mathrm{g}$ of lactoferrin) were injected into the column. The heating temperature of $\mathrm{Lf}$ is indicated on each chromatogram. The peak of native Lf is indicated by an arrow. Unheated Lf and FeLf (the mixture of unheated lactoferrin and iron(III) chloride in the presence of $\mathrm{NaHCO}_{3}$ ) are also shown (Unheated) 

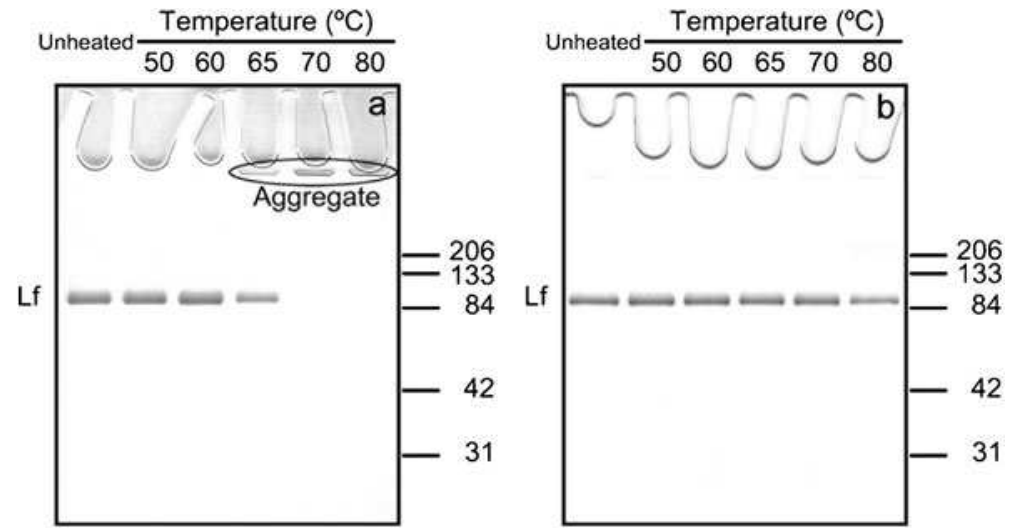

Fig. 3 Typical non-reducing (a) and reducing (b) sodium dodecyl sulphate polyacrylamide gel electrophoresis patterns of heat-treated lactoferrin $(L f)$. The heating temperature of $\mathrm{Lf}$ is shown on each lane. The aggregates are indicated in the circle. The molecular mass standard is labelled on the right (in kilograms per mole). Unheated Lf is shown on the left in each gel

\subsection{Effect of Tf, $\alpha \mathrm{La}$ and $\beta \mathrm{Lg}$ on iron solubilization with $\mathrm{HCO}_{3}{ }^{-}$}

Various proteins were substituted for $\mathrm{Lf}$ to prepare protein/Fe. The turbidity and soluble proteins of protein/Fe are shown in Table 4 . Fe(III) was precipitated and not detected in the supernatants of any mixtures, except that containing unheated Lf. The concentrations of the soluble proteins did not change in any of the samples after the addition of $\mathrm{Fe}(\mathrm{III})$, whereas their turbidity, which is an indicator of $\mathrm{Fe}(\mathrm{III})$ precipitation, changed slightly in FeLf.

\section{Discussion}

Lf and enzymatically digested Lf can solubilize more than 70 molar equivalents of iron, whereas the iron-solubilizing ability of casein phosphopeptide, derived from casein by

Table 4 Turbidity, concentrations of soluble protein and iron in the mixtures of proteins and iron(III) chloride (protein/Fe) in $\mathrm{NaHCO}_{3}$

\begin{tabular}{|c|c|c|c|c|c|}
\hline \multirow[t]{2}{*}{ Protein } & \multicolumn{2}{|c|}{ Turbidity $\left(A_{600}\right)$} & \multicolumn{2}{|c|}{ Soluble protein $\left(\mathrm{mg} \cdot \mathrm{mL}^{-1}\right)$} & \multirow[t]{2}{*}{ Soluble iron $\left(\mathrm{mmol} . \mathrm{L}^{-1}\right)$} \\
\hline & Protein & Protein/Fe & Protein & Protein/Fe & \\
\hline Unheated Lf & $0.005 \pm 0.003$ & $0.068 \pm 0.012$ & $4.04 \pm 0.14$ & $3.96 \pm 0.07$ & $5.0 \pm 0.1$ \\
\hline Transferrin & $0.039 \pm 0.016$ & $0.281 \pm 0.311$ & $3.99 \pm 0.08$ & $3.90 \pm 0.16$ & N.D. \\
\hline$\alpha$-Lactalbumin & $0.006 \pm 0.002$ & $0.828 \pm 0.083$ & $4.05 \pm 0.09$ & $4.12 \pm 0.17$ & N.D. \\
\hline$\beta$-Lactoglobulin & $0.005 \pm 0.001$ & $0.350 \pm 0.082$ & $3.91 \pm 0.17$ & $4.00 \pm 0.17$ & N.D. \\
\hline No protein & $0.000 \pm 0.001$ & $0.506 \pm 0.053$ & N.D. & N.D. & N.D. \\
\hline
\end{tabular}

Protein shows the mixtures in $4.0 \mathrm{mg} \cdot \mathrm{mL}^{-1}$ of each protein and $25 \mathrm{mmol} \cdot \mathrm{L}^{-1} \mathrm{NaHCO}_{3}$ without iron(III) chloride. All values were shown in mean $\pm \operatorname{SD}(n=3)$

N.D. not detected 
proteolysis, is $<10^{-1}$ that of $\mathrm{Lf}$ (Kawakami et al. 1993). $\beta$-Caseinophosphopeptide $\left(\beta-\mathrm{CN}_{1-25}\right)$ can also facilitate iron absorption and has antioxidant activity similar to that of FeLf. In contrast to FeLf, the structure-function relationship of $\beta-\mathrm{CN}_{1-25}$ is well characterized (Kansci et al. 2004). The objective of this study was to extend our understanding of iron solubilization by $\mathrm{Lf}$ in the presence of bicarbonate anions to develop a manufacturing process and appropriate applications for FeLf.

It has been proposed that $\mathrm{Lf}$ is involved in various biological functions, such as antimicrobial activity, iron absorption and immunoregulation (Lönnerdal 2009; Steijns and van Hooijdonk 2000; Wakabayashi et al. 2006). However, the thermal treatment of Lf reduces some of its biological activities (Kussendrager 1994; Oria et al. 1993; Paulsson et al. 1993). The thermal denaturation of Lf has been well studied under many experimental conditions, including different $\mathrm{pH}$ values, buffers and concentrations of buffer salts (Abe et al. 1991; Kawakami et al. 1992). When Lf was heated near its isoelectric point (Table 3), the denaturation temperature (about $65^{\circ} \mathrm{C}$ ) was consistent with that in the literature (Hu et al. 2008). We also only observed an iron solubilization capacity in native Lf, which was lost after its thermal denaturation (Fig. 1 and Table 1). These results suggest that iron solubilization by Lf is also one of the functional characteristics of native Lf. Once Lf is thermally denatured during food processing, as during pasteurization, it cannot solubilize iron. Therefore, we consider that the preparation of FeLf requires native Lf. Successfully manufactured FeLf should also be "native," that is, containing biologically active Lf. The multifunctional benefits of Lf can also be delivered to the consumer as FeLf.

$\mathrm{Tf}$ is a homologue of Lf, with $60 \%$ amino acid sequence identity to Lf. $\alpha$ La and $\beta \mathrm{Lg}$ constitute about $70 \%$ of whey proteins (Blaschek et al. 2007), which are a major source of $\mathrm{Lf}$ in the food industry. In contrast, $\mathrm{Tf} / \mathrm{Fe}, \alpha \mathrm{La} / \mathrm{Fe}$ and $\beta \mathrm{Lg} / \mathrm{Fe}$ precipitated without any change in the concentrations of soluble protein (Table 4), whereas HT-Lf/Fe caused a large reduction in soluble Lf (Table 1). These results suggest that this iron-solubilizing capacity is characteristic of Lf. In terms of the interactions between milk proteins and transition metals, Chakraborty and Basak (2008) reported that $\mathrm{Al}(\mathrm{III})$ and $\mathrm{Zn}$ (II) cause the aggregation of caseins by inducing structural changes in them. As shown in Table 2, among various cations, only Fe(III) induced the precipitation of HT-Lf and the soluble HT-Lf was greatly decreased only in HT-Lf/Fe (III), suggesting that Fe(III) affects the solubility of HT-Lf. Cu(II) and $\mathrm{Zn}$ (II) did not affect the soluble HT-Lf even though these metals also precipitated in HT-Lf/Cu (II) or HT-Lf/Zn(II) (data not shown). In contrast, Fe(III) precipitated alone in the mixtures of Tf, aLa and bLg (Table 4). Therefore, HT-Lf/Fe(III) could form insoluble complex and precipitate. In the manufacturing process of FeLf, the use of unpurified or thermally denatured Lf could affect iron solubilization by exceeding the feasible ratio of iron per unit Lf or by inducing an unfavourable interaction between denatured Lf and Fe(III).

The molecular masses of HT-Lf and HT-Lf/Fe suggest that thermally denatured Lf cannot remain soluble because of the loss of its iron-solubilizing capacity (Figs. 1 and 2 and Table 3). The thermal treatment of Lf induced its aggregation by the formation of intermolecular disulfide bonds, which consequently increased its molecular weight (Brisson et al. 2007a). Bovine Lf is a 689-amino acid polypeptide, with 17 disulfide bonds and no free cysteine residues (Pierce et al. 1991). When Lf was heated at 70 or $80{ }^{\circ} \mathrm{C}$ and subjected to SDS-PAGE under reducing conditions, 
the aggregate dissociated into monomeric Lf molecules (Fig. 3). This result indicates that the formation of the aggregates could result from the formation of intermolecular disulfide bonds between denatured Lf, like the formation of the protein-protein complexes observed in heated skim milk (Brisson et al. 2007b; Donato and Guyomarc'h 2009). In other words, the higher-level structure of denatured Lf could change, forming soluble aggregates. According to the structural model proposed by $\mathrm{Hu}$ et al. (2008), the surface charge on $\mathrm{Lf}$ is responsible for the formation of FeLf. Considering that digested Lf still has an iron-solubilizing capacity (Kawakami et al. 1993), HT-Lf could be affected by steric hindrance in the region of $\mathrm{Lf}$ involved in iron solubilization.

\section{Conclusions}

Heated Lf was precipitated by the addition of Fe(III), and no soluble Lf or soluble iron was detected. In contrast, the addition of $\mathrm{Cu}$ (II), $\mathrm{Zn}$ (II), $\mathrm{Mg}$ or $\mathrm{Na}$ instead of Fe(III) had little effect on the solubility of heated Lf. This precipitation event corresponded to the thermal denaturation of Lf, accompanied by an increase in its molecular mass and the formation of soluble aggregates. The iron-solubilizing capacity of Lf was lost by its thermal denaturation, together with some of the biological functions of Lf. Tf, $\alpha \mathrm{La}$ and $\beta \mathrm{Lg}$ did not solubilize Fe(III) in the presence of bicarbonate anions, suggesting that this iron solubilization capacity is characteristic of Lf. In conclusion, native Lf can solubilize iron in the presence of bicarbonate anions during the manufacture of FeLf. FeLf supplementation can improve specific food products by supplementing their iron content and other nutritional functionalities.

\section{References}

Abe H, Saito H, Miyakawa H, Tamura Y, Shimamura S, Nagao E, Tomita M (1991) Heat stability of bovine lactoferrin at acidic $\mathrm{pH}$. J Dairy Sci 74:65-71

Baker EN, Baker HM (2009) A structural framework for understanding the multifunctional character of lactoferrin. Biochimie 91:3-10

Baker EN, Baker HM, Kidd RD (2002) Lactoferrin and transferrin: functional variations on a common structural framework. Biochem Cell Biol 80:27-34

Blaschek KM, Wendorff WL, Rankin SA (2007) Survey of salty and sweet whey composition from various cheese plants in Wisconsin. J Dairy Sci 90:2029-2034

Brisson G, Britten M, Pouliot Y (2007a) Heat-induced aggregation of bovine lactoferrin at neutral pH: effect of iron saturation. Int Dairy J 17:617-624

Brisson G, Britten M, Pouliot Y (2007b) Effect of iron saturation on the recovery of lactoferrin in rennet whey coming from heat-treated skim milk. J Dairy Sci 90:2655-2664

Chakraborty A, Basak S (2008) Interaction with Al and $\mathrm{Zn}$ induces structure formation and aggregation in natively unfolded caseins. J Photochem Photobiol B 93:36-43

Donato L, Guyomarc'h F (2009) Formation and properties of the whey protein/K-casein complexes in heated skim milk — a review. Dairy Sci Technol 89:3-29

Hu F, Pan F, Sawano Y, Makino T, Kakehi Y, Komiyama M, Kawakami H, Tanokura M (2008) Studies of the structure of multiferric ion-bound lactoferrin: a new antianemic edible material. Int Dairy J 18:1051-1056

Hurrell RF (1997) Preventing iron deficiency through food fortification. Nutr Rev 55:210-222

Kansci G, Genot C, Meynier A, Gaucheron F, Chobert JM (2004) ß-Caseinophosphopeptide (f1-25) confers on $\beta$-casein tryptic hydrolysate an antioxidant activity during iron/ascorbate-induced oxidation of liposomes. Lait 84:449-462 
Kawakami H, Shinmoto H, Dosako S, Sogo Y (1987) One-step isolation of lactoferrin using immobilized monoclonal antibodies. J Dairy Sci 70:752-759

Kawakami H, Tanaka M, Tatsumi K, Dosako S (1992) Effects of ionic strength and pH on the thermostability of lactoferrin. Int Dairy J 2:287-298

Kawakami H, Dosako S, Nakajima I (1993) Effect of lactoferrin on iron solubility under neutral conditions. Biosci Biotechnol Biochem 57:1376-1377

Kussendrager KD (1994) In: International Dairy Federation (ed) Indigenous antimicrobial agents of milk -recent developments. International Dairy Federation, Brussels

Laemmli UK (1970) Cleavage of structural proteins during the assembly of the head of bacteriophage T4. Nature 227:680-685

Lönnerdal B (2009) Nutritional roles of lactoferrin. Curr Opin Clin Nutr Metab Care 12:293-297

Motouri M, Yoshise RE, Matsuyama H, Hosoya T, Kadooka Y, Asada C, Uchida T, Kawakami H (2007) Effect of iron solubilized by lactoferrin on iron status in adult women. Nippon Shokuhin Kagaku Kogaku Kaishi 54:442-446 (in Japanese)

Oria R, Ismail M, Sánchez L, Calvo M, Brock JH (1993) Effect of heat treatment and other milk proteins on the interaction of lactoferrin with monocytes. J Dairy Res 60:363-369

Paulsson MA, Svensson U, Kishore AR, Naidu AS (1993) Thermal behavior of bovine lactoferrin in water and its relation to bacterial interaction and antibacterial activity. J Dairy Sci 76:3711-3720

Pierce A, Colavizza D, Benaissa M, Maes P, Tartar A, Montreuil J, Spik G (1991) Molecular cloning and sequence analysis of bovine lactotransferrin. Eur J Biochem 196:177-184

Shiota M, Uchida T, Oda T, Kawakami H (2006) Utilization of lactoferrin as an iron-stabilizer for soybean and fish oil. J Food Sci 71:C120-C123

Steijns JM, van Hooijdonk ACM (2000) Occurrence, structure, biochemical properties and technological characteristics of lactoferrin. Br J Nutr 84:S11-S17

Uchida T, Oda T, Sato K, Kawakami H (2006) Availability of lactoferrin as a natural solubilizer of iron for food products. Int Dairy J 16:95-101

Wakabayashi H, Yamauchi K, Takase M (2006) Lactoferrin research, technology and applications. Int Dairy J 16:1241-1251

Worldwide prevalence of anaemia 1993-2005: WHO global database on anaemia (2008). World Health Organization, Geneva. http://www.who.int. Accessed 2008

Yamauchi K, Soejima T, Ohara Y, Kuga M, Nagao E, Kagi K, Tamura Y, Kanbara K, Fujisawa M, Namba S (2004) Rapid determination of bovine lactoferrin in dairy products by an automated quantitative agglutination assay based on latex beads coated with $\mathrm{F}\left(\mathrm{ab}^{\prime}\right)_{2}$ fragments. Biometals 17:349-352

Yoshise RE, Matsuyama H, Hosoya T, Ogawa A, Kadooka Y (2010a) Effects of Fe-lactoferrin via oral administration on mental stress. Milk Sci 59:93-101 (in Japanese)

Yoshise RE, Ueda N, Matsuyama H, Serizawa A (2010b) Suppressive effect of lactoferrin with 70 irons via oral administration on dysmenorrheal. Milk Sci 59:115-123 (in Japanese) 